\title{
A STUDY ON THE TOURIST INTERPRETATION APPLIED IN SULTAN AHMAD 1 MOSQUE, KUANTAN, PAHANG DARUL MAKMUR
}

\author{
Mohamad Zulhilmy Bin Mohamad Yusop ${ }^{1}$; Rosilah Bt Man ${ }^{2}$ \\ ${ }^{2}$ Department of Tourism and Hospitality \\ Politeknik METrO Kuantan (PMKu) \\ ${ }^{1}$ Pahang, Malaysia
}

\begin{abstract}
Nowadays, Islamic tourism has grown rapidly due to the variance of attractions offered, such as Muslim-friendly hospitality, 'halal' food restaurants and the unique architecture of the mosques that known as 'mosque tourism', which also affects the growth of Islamic tourism in Malaysia. The most successful mosque tourism attraction is National Mosque which located in Kuala Lumpur. The state of Pahang has a great potential in attracting tourist arrival; besides the natural heritage such as National Park, it also has a huge potential in mosque tourism attraction in particularly, Mosque of Sultan Ahmad 1 or popular known as the Pahang State Mosque. However the mosque somehow is lacking in visitors interpretation; the main key to facilitate and attract visitors especially for non-Muslims. Interpretation is needed to educate people that aim to reveal meanings and relationships through the use of original objects; by the first-hand experience and illustrative media, rather than simply communicating factual information. From the interviews and observations conducted by the researchers, these routes are divided into five parts: the interpretation routes, tourist robe, tourist information center, screening room and media publication. These five parts of interpretation should exist to make the Islamic mosque tourism in Pahang State Mosque more attractive. There are nine suggested routes that can be implemented in the mosque. Route 1: The introduction of Sultan Ahmad 1 Mosque and the explanation on how to wear a tourist robe. 2: The purpose and practice of the ablution. 3: The main prayer hall. 4: The explanation on the design of the mosque's pillars. 5: The male and female prayer hall. 6: The information of mosque's dome. 7: The information of Imam and 'mimbar'. 8:

The prayer hall view from the upper level. Lastly, 9: The interactive video about the mosque. Some of the interpretations are already applied in the mosque, but somehow it needs to be improved in order to give a better explanation to the visitors in understanding the Islam religion and its culture in Malaysia and indirectly exposing the beauty of Islam.
\end{abstract}

Keywords: Mosque Tourism and Tourist Interpretation Routes.

\section{INTRODUCTION}

In Malaysia, Islamic tourism was first introduced in the 1980s. At that time, mosques are the most synonymous with Islamic tourism. Islamic tourism is now expanding to the form of Islamic tourism activities, Muslim-friendly destination, and halal cuisine restaurants. Nowadays, mosques in Malaysia are built with its own uniqueness.

The most attractive mosque is the National Mosque in Kuala Lumpur. According to the reports from Ghafani Awang Teh (2008), the National Mosque welcomed approximately 255,800 foreign tourists throughout the year of 2007 . Therefore, Sultan Ahmad 1 Mosque, Kuantan or popular known as Pahang State Mosque, also has a potential to become a major attraction in Kuantan though the number of foreign tourists to Kuantan town in 2010 were not as many as in Kuala Lumpur, a total of 42,248 people, and local tourists as many as 758,959 people (Pahang Tourism, 2013). In 2014, foreign tourist arrival statistics (other ASEAN) to the state has been reduced compared to 2013, from 1,275,369 people to 908,366 people (Tourism Pahang, 2015). However, based on interviews with Fadzli Bin Haji Mat Saman (2015), Imam of Pahang Sate Mosque (S48), the mosque has been visited by foreign tourists who stay in Kuantan.

Design features such as a large dome of the mosque, light blue and white striped in colour, together with its 180-feet tower, make it stands out against the buildings in Kuantan. From the air view and Tanjung Lumpur Bridge, Pahang State Mosque building structure is clearly visible. Perhaps this feature is one of the attraction factors that influenced tourists to visit the mosque which heightens their curiosity and fascination. In addition, there are also many other factors that encourage tourists to the mosque. Ghafani Awang Teh (2008), in his state, "when visiting mosques, things become a tourist attraction, especially non-Muslim tourists, are the beauty of the tower, the architecture of the mosque, the mihrab (where Imam pray), the mimbar (where a person read the Friday sermon), ambience serenity of interior decoration, a place of ablution, the role of Imam, musicality muezzin's voice (prayer call), the role of the prayer and how Muslims pray."

According to him, it is not easy to attract tourists to come and visit mosques, hence, the management can take certain steps such as providing information about the history of the mosque, clean and cheerful environment and comfortable toilet facilities. Similar to the internal functions of the mosque; 
parking services, extensive promotion to the local community and guide services and also exhibition space and gallery also need to be provided.

However, there are a few things during the visit that must be maintained in order not to violate the Islamic laws, particularly, the fact that some tourists who visit the Pahang State Mosque are non-Muslims. According to Noor Shakirah Mat End (2010), which is not the prayer, is responsible for the upkeep of the surrounding areas visited, ensure food is 'halal', wear clothes that cover themselves, using 'halal' sources for all travel expenses and activities that do not conflict with Islam during the journey (Jabil Mapjabil, 2015).

Researchers trying to understand the problems faced by the Pahang State Mosque and also answer questions among industry players such as tourist guides and travel agents. The significant problem is that the mosque's visitor management itself should provide the mosque interpretation route that describes the beauty of the design and reasons for the Islamic practices done in the mosque such as ablution, the five daily prayers, congregational prayers, prayer calling, Friday sermon and so on. This interpretation route should be dealt with in order to facilitate not only tourists visiting in groups or alone, but also accompanied by a tour guide or not.

Freeman Tilden (1957) defines interpretation as visitor education activities that aim to reveal meanings and relationships through the use of original objects, a first-time experience, and by illustrative media, rather than simply to communicate factual information. On the issue of Interpretation Canada (1976) defines interpretation as a communication process designed to reveal meanings and relationships of the natural heritage and our culture, to the public, through direct experience with objects, artifacts, landscape, or sites (John A. Veverka, 2011).

Tilden also revealed SIX (6) principles of the visitor interpretation. Here is a summary of those principles:

i. Any interpretation must be related to what is shown or described to something related to personality or visitor experience.

ii. Information is not interpretation. The interpretation is based on the disclosure of information. However, all interpretation is information.

iii. Interpretation is an art, which combines many arts, whether the materials presented are scientific, historical or architectural interest. Any art at several levels can be taught.

iv. The main purpose of the interpretation is not instruction, but provocation.

v. Interpretation should aim to present whole and not in part, instead of any phase.

vi. Interpretation addressed to children (up to the age of twelve) should not be approached for adults, but must follow a different approach. To be the best, it requires a separate program. (Freeman Tilden, 1957)
Veverka (2011) also says that interpretation is not uncommon to be displayed on billboards or any derivatives because the present-day interpretation mostly not real but merely a mere information. Therefore, the interpretation to be established at the Pahang State Mosque should be "interpreted" by following the principles of Tilden's interpretation, not too grand or great.

Actual interpretation: (Provoke) Sparking interest in visitors; (Relate) Relate to their daily lives in some way; (Reveal) Reveal ideas or information in a creative, unique or memorable; (Whole) State the overall theme of interpretation in all things; and (Arts) Messages properly integrated with graphics, colours, and other things that support (John A. Veverka, 2011).

An important aspect in discussing the concept of Islamic tourism is a significant difference compared to commercial travel. In general, commercial tourism prioritizes profitability and customer satisfaction compared to Islamic tourism which puts the pleasure of Allah S.W.T as the main goal (Graburn, 1977).

\section{METHOD}

The researchers interviewed several respondents by using In-Depth Semi-Structural Interviews Technique. A qualitative study of interview method is a way to get what others feel and think based on their own perspective.

For additional important information to support the description of the facts in this study, the researchers used a technique of gathering information from a second source through publications, articles, blog and website to help researchers to analyse and critique the tourist interpretation route.

The study used the following methods to obtain data:

i. Interview - Based on interviews conducted with the interviewee:

- Mr. Haji Mohd Fadzli Bin Mat Saman, Imam of Sultan Ahmad 1 Mosque, Kuantan, Pahang (S48)

- Mr. Nasa Bin Amar, Security Guard (temporarily act as visitor guide) of Sultan Ahmad 1 Mosque, Kuantan, Pahang

ii. Observation - The study also used the observation method based on monitoring and research, at the study site.

\section{FINDING AND DISCUSSION}

Pahang State Mosque has an area that can accommodate more than 80,000 worshippers at any one time. This area includes several rooms that have specific purposes such as prayer area for men is located on the ground floor and in the middle of the mosque. The room is covered with green and blue carpet in front of the pulpit. Women's prayer area in the back of the ground floor and first floor covered with white 
Marble floors. Prayer area for men also includes the rest of the ground floor, especially during Friday prayers.

At the first floor, there is a lot of rooms and halls at the left and right wings of the mosque, other than the female prayer room at the back. The rooms and halls are used as religious classes as Takmir (enliven the mosque) and KAFA - Kelas Agama dan Fardu Ain (religion and basic obligatory classes). While the halls are used for large programmes, for example, the Islamic Religious Studies Certification Programme (Tafaqquh Fiddin) of Pahang State.

There are other rooms in Pahang State Mosque such as (i) the administration office at the back of the mimbar which is located at the front of the building, (ii) cafeteria / canteen, (iii) ablutions chamber, (iv) toilet, (v) ICT informative corner, (vi) security counter, (vii) robe storage room, (viii) footwear and goods placement, (ix) resting hut (wakaf), and (x) the external environment of the mosque.

Looking at the size of the internal space of the mosque, it is a walk-in space that can hold tourists without disturbing the observances and other users of the mosque.

Based on the interview with the Imam of the mosque, Mr. Haji Fadli Bin Haji Mat Saman said that Pahang State Mosque has received the visit from tourists, especially tourists who stay in hotels around the Kuantan city. Tourists are normally considered and taken into the internal space of the mosque by the mosque officers and security guards. According to Haji Fadli, the mosque welcomes tourists to come to visit, especially non-Muslim tourists to see the beauty of the mosque and indirectly learn about Islam. Almost all the spaces in the mosque are not for them, but their prohibition could comply with etiquette when visiting a mosque as they need to cover themselves and not disturbing others who are worshipers of the mosque.

Other than a briefing from mosque officers, foreign tourists usually prefer to ask questions about the mosque and Islam to the Muslims who are resting inside the mosque. (Fadli Mat Saman, personal communication, December 15, 2015)

Pahang State Mosque has predetermined tour times, which are (1) $10.00 \mathrm{am}-12.00 \mathrm{pm}$, (2) $3.00 \mathrm{pm}-4.00 \mathrm{pm}$, and (3) $5.30 \mathrm{pm}$ and $6.00 \mathrm{pm}$. The tour times are displayed on signboard along the main entrance outside the mosque. Even though the signboard is placed near the main door, still one person cannot notice it because the eyes will focus on the inside of the mosque.

Dato' Haji Mohd Ghazali bin Abdul Aziz, Deputy Director of the Pahang Islamic Religious Department (JAIP) believes there is a section / area in the Pahang State Mosque in future could be used by tourists without disturbing the mosque, especially during prayer time. He suggested the section / space on the first floor which is being renovated for air-conditioner replacement can be used for the tourist route.

While special clothing such as hooded robe is available at the state mosque. According to Kuantan District Islamic Religious Officer, Mr. Haji Abd. Zaki Bin Md. Zin, the robes are stored in a room next to security counter. To use it, one must first obtain permission from the security guard. However,
Mr. Adi Din Bin Husin, Director of East Coast Holiday (travel agent) and Mr. Francis Francis Loh Boon Hor, Secretary of Pahang Tourist Guides Association (tourist guide) comment on the difficulty of getting the agent and tourist guide who bring the foreign tourist to get inside because of the absent officer and proper tourist counter for them to ask question by time they arrived.

\section{CONCLUSION AND SOLUTION}

The main recommendation is for the enhancement of the tourist interpretation route of Pahang State Mosque and it is derived from observation, interviews and the researchers concluded.

The proposal of tourist interpretation route of Pahang State Mosque is divided into several sections. In addition, other proposals are responses to the industry player complaint, as well as to facilitate the tourists to visit the mosque and travel agents to bring tourists to the mosque.

There are many situations how tourists come to visit the mosque. These situations will make the explanation different with each of it. The situation is (i) tourist visits with tourist guide or guided by the mosque officer; or (ii) tourist independently visit in a group or solo.

For that, the mosque should also have a guided tour tool that makes the interpretation route works better with or without staff guiding the tourists; for example lots of brochure publication, interpretive board, touch screen displays, guided walk and tourist information center.

The researchers suggested the Tourist Interpretation Route at Pahang State Mosque needs to be built and shown to the public, meaning that, the route maps will be displayed on the interpretation boards in the mosque (at tourist information center) and published in a brochure so that tourists and travel agencies clearly understand about the areas they are supposed to pass through. The intention is to ensure the serenity of the mosque without disturbing other users, furthermore, to enhance the tourist visiting system at the mosque.

Along this route, there are stops for tourists to read the information either on interpretation boards or in a brochure, or a short briefing by the visitor officer. The visitor officer may come from a mosque officer itself or a tour guide from the travel agency. However, some tour guides are non-Muslims; it is encouraging to have some eligible staffs from the mosque that have skills and knowledge as to explain on the religious part.

Tourist Interpretation Route of the Pahang State Mosque has NINE (9) stops starting from the main entrance of the mosque located at the left of the mosque (Figure 1). The suggested stops are the perfect place to for the explanation about Pahang State Mosque's beauty to be given. 

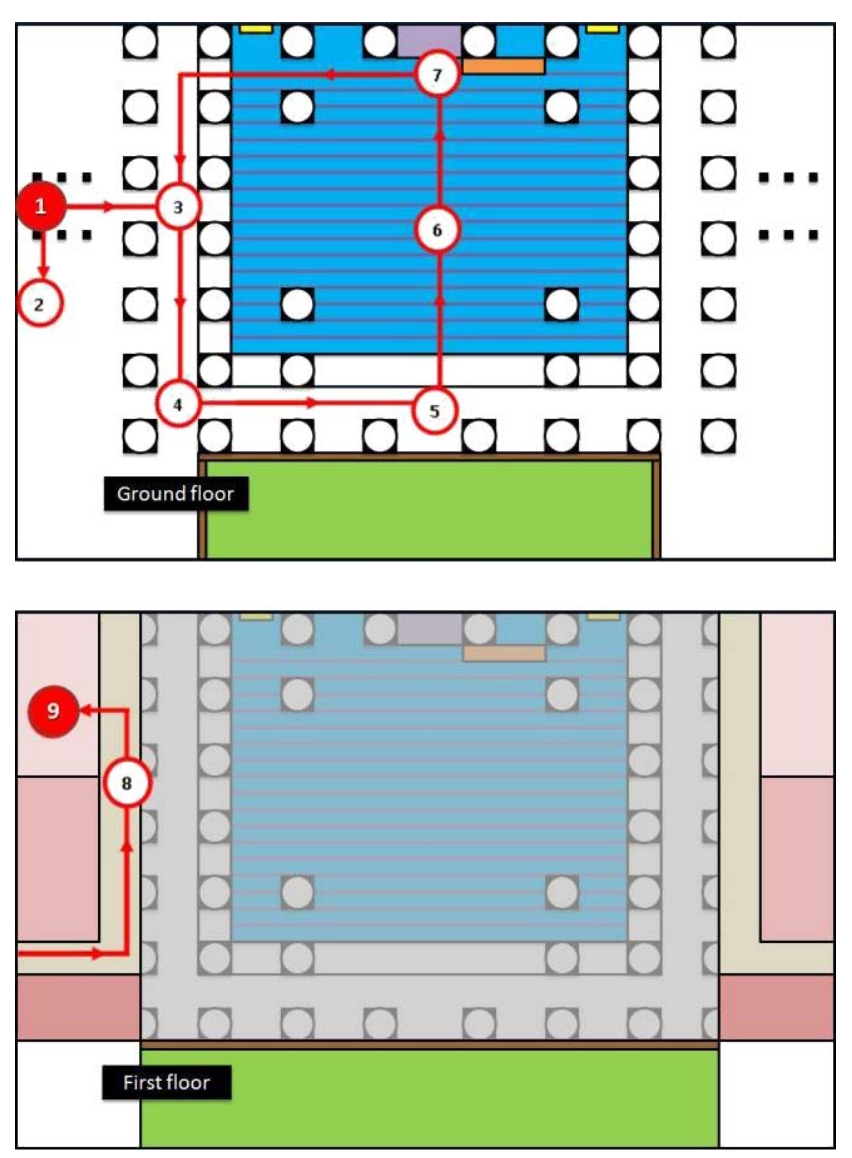

Figure 1: The illustration of tourist interpretation route; ground floor (above) and first floor (below)

The security counter or tourist information center-to-be will be the first stop. This counter is a place where tourist will be asked to wear a robe to cover their revealing bodies (aurat) before entering the mosque. It is also a right place to explain on the obligation to cover their bodies properly in an Islamic way.

Here are NINE (9) Stops of Tourist Interpretation Route and explanation at each stop:

i. First stop (1): Introduction of Sultan Ahmad 1 Mosque / tourist robe apparel

ii. Second stop (2): Purpose and practice of the ablution

iii. Third stop (3): Main prayer hall

iv. Fourth stop (4): Internal design, architectural, pillars and glass windows of the mosque

v. Fifth stop (5): Male (muslimin) and female prayer (muslimat) hall

vi. Sixth stop (6): Dome of the mosque

vii. Seventh stop (7): Role of Imam and mimbar

viii. Eighth stop (8): Prayer area view from the first floor.

ix. Ninth stop (9): Video screening / slide show about the mosque / Islam

The first to seventh stop covers the main areas on the ground floor (lower level) of the mosque. Meanwhile, the eighth and ninth stop covering the area on the first floor (upper level). To go to the first floor, one has to use the stairs at the left and right of the mosque and through the aisle through the small rooms that were used for religious classes.

To get a clearer picture of this interpretation route and stops, see Figure 1 above shows the top view of the main area of the Pahang State Mosque and the interpretation route and stops at the ground floor and the first floor. The route starts from the main entrance at the left of the mosque as a first stop until the ninth stop at the first floor as the last stop.

The Tourist Interpretation Route of Pahang State Mosque is expected to address the problems faced by the industries ranging from tourists, tour guides, travel agencies and State Mosque itself. Problems faced and discussed by the industry at Polytechnic METrO of Kuantan (PMKu) can be solved with this interpretation route, particularly on the part of the State Mosque in terms of the tourist reception who visit the mosque and the use of robes. The improvement of the mosque at the first floor is also directly paved the way for a wider corridor and can be used for tourist trips in the future.

This interpretation route makes it easier for tourists to get information about the mosques and Islamic culture itself, thereby increases tourist arrivals to the mosque and makes the mosque as one of the tourist destinations in Kuantan, Pahang. Although this tour is free, the beauty of mosques and Islamic religion should be highlighted and made known to the outside world as to get rid of negative views toward Islam today.

In addition, $\mathrm{PMKu}$ has carried out some research proposals to the mosque in increasing tourist arrivals such as:
i. Islamic Explorace Competition
ii. World Islamic Tourism Mart
iii. Exhibition of Islamic Tourism
iv. Blogspot of Pahang State Mosque

\section{REFERENCES}

[1] “Comparison Between Tourist Arrival 2013 \& 2014 By Country To Pahang”. (2015, May 27). Retrieved from http://www.pahangtourism.org.my/index.php/travelinfo/downloads/doc_download/15-statistik-2014-2013

[2] Freeman Tilden (1957, 1967, 1977), "Interpreting Our Heritage Third Edition". The University of North Carolina Press, Chapel Hill

[3] Ghafani Awang Teh (2008, Mac 1). "Mosque as a Tourism Destination / Masjid Sebagai Destinasi Pelancongan". Berita Harian. Retrieved from $\mathrm{http}: / / w w w . i s l a m . g o v . m y / e n / m a s j i d-s e b a g a i-d e s t i n a s i-p e l a n c o n g a n-$ ghafani-awang-tehberita-harian-132008

[4] Graburn NH (1977), "Tourism: The Sacred Journey. In: Smith V (Ed) Hosts and Guests: The Anthropology of Tourism, pp.17-31". University of Pennsylvania Press, Philadelphia.

[5] Jabil Mapjabil, Ratna Roshida Abd Razak, Mazdi Marzuki, Rosmiza Mohd Zainol (2015), "Islamic Tourism: A Conceptual Overview and Its Relevance in Malaysia / Pelancongan Islam: Suatu Tinjauan Konseptual dan Relevannya di Malaysia”, GEOGRAFIA OnlineTM Malaysia Journal of Society and Space 11 issue 1, ISSN 2180-2491

[6] John A. Veverka (2011), "Interpretive Master Planning: Volume 2 - Selected Essays: Philosophy, Theory and Practice". MuseumsEtc.

[7] Mohd. Radzi Mohd. Zin (2011, Jan 4). "Da'wah Through Mosque Tourism / Dakwah Melalui Pelancongan Masjid”. Utusan Malaysia. Retrieved from http://ww1.utusan.com.my/utusan/info.asp?y=2011\&dt=0104\&pub=Utu san_Malaysia\&sec=Bicara_Agama\&pg=ba_04.htm 
[8] Noor Shakirah Mat Akhir (2010), "Islamic Tourism: A Conceptual Framework. Proceedings of Regional Conference on Tourism Research (RCTR 2010)". Universiti Sains Malaysia, Penang.
[9] “Tourist Arrival By Country To Pahang”. (2013, April 12) Retrieved from http://www.pahangtourism.org.my/index.php/travelinfo/downloads/doc download/6-statistik-2010 